\title{
THE ROLE AND IMPORTANCE OF RENEWABLE ENERGY IN THE FREE TRADE AGREEMENTS OF THE EUROPEAN UNION*
}

\section{Halil ÇEÇEN**}

\section{Abstract}

The aim of this article is to assess how the Directive 2009/28/EC and Directive 2018/2001, which respectively contain the EU's 2020 and 2030 objectives related to increasing the share of renewable energy sources in total energy consumption, are reflected in the free trade agreements concluded by the EU with third states. This article argues that the acquis communautaire shapes the provisions of EU's free trade agreements pursuant to the articles in the Directive 2009/28/EC and Directive 2018/2001 which state that the EU may cooperate with third states in the field of renewable energy. On the basis of this argument and within the framework of EU's Common Commercial Policy, this article examines the provisions concerning renewable energy in the free trade agreements which have been concluded by the EU with third states and entered into force. One of the findings of this article is that, thanks to its background and experience embodied in its acquis communautaire, the EU gives direction to the international renewable energy law and trade as a result of its free trade agreements with third states, and in this way, ensures formation of a uniform acquis in this field. Another finding of the article is that the EU became stronger in shaping the international law and the acquis communautaire gained importance as a result of the Common Commercial Policy, which covers trade and investment in renewable energy as well, being discussed at the Union level after the Treaty of Lisbon.

Keywords: renewable energy, free trade agreements, EU energy policy, promotion of investments, common commercial policy.

\footnotetext{
* An earlier version of this article has been presented at the Marmara Conference on European Studies 2020 (MCES-2020), İstanbul, 7-8 February, 2020.

** Lecturer and the Coordinator of Mehmet Akif Ersoy University Vocational School of Social Sciences, Department of Law, Justice Program, e-mail: hcecen@mehmetakif.edu.tr.
} 


\section{AVRUPA BİRLİĞI'NIN SERBEST TİCARET ANLAŞMALARINDA YENILENEBİLIR ENERJININ YERI VE ÖNEMI \\ $\ddot{O} z$}

Bu makalenin amaci, yenilenebilir enerji kaynaklarınin toplam enerji tüketimindeki payının arttırlmasına yönelik olarak AB'nin 2020 hedeflerini içeren 2009/28/EC sayll Direktifi ile 2030 hedeflerini içeren 2018/2001 sayll Direktif'indeki hükümlerin AB'nin üçüncü devletlerle akdettiği serbest ticaret anlaşmalarına yansımalarının değerlendirilmesidir. Bu makalede ileri sürülen argüman ise, 2009/28/EC ve 2018/2001 sayll Direktiflerin, AB'nin yenilenebilir enerji alanında üçüncü devletlerle işbirliği yapabileceğine dair maddeleri uyarınca, $A B$ müktesebatının AB'nin serbest ticaret anlaşmalarındaki hükümleri şekillendirdiğidir. Bu argümana dayalı olarak, AB'nin üçüncü devletlerle akdettiği ve yürürlüğe giren serbest ticaret anlaşmalarındaki yenilenebilir enerjiye dair hükümler, AB'nin Ortak Ticaret Politikası çerçevesinde incelenmiştir. Makalede varlan sonuçlardan birisi, AB'nin yenilenebilir enerji alanında kendi müktesebatındaki birikimi ve tecrübesi sayesinde, üçüncü ülkeler ile akdettiğ $i$ serbest ticaret anlaşmalarının bir sonucu olarak, uluslararası yenilenebilir enerji hukukuna ve ticaretine yön verdiği ve böylece bu alanda yeknesak bir müktesebatın oluşmasını sağladığıdır. Makalede varılan bir diğer sonuç ise, Lizbon Anlaşması sonrasinda, yenilenebilir enerji ticaretini ve bu alandaki yatırımlart da kapsayan Ortak Ticaret Politikasının Birlik düzeyinde ele alınmasının bir sonucu olarak AB'nin uluslararası hukuku şekillendirmede daha güçlendiği ve AB hukukunun önem kazandı̆̆ıdır.

Anahtar Kelimeler: yenilenebilir enerji, serbest ticaret anlaşmaları, AB enerji politikası, yatırımların teşviki, ortak ticaret politikası.

\section{Introduction}

The aim of this article is to determine how free trade agreements ("FTA"s) are affected by the provisions in the Directive 2009/28/EC and Directive 2018/2001 which state that the EU may cooperate with third states to reach its 2020 and 2030 targets. Moreover, this article also deals with the problem of ascertaining whether a uniform legislation has been formed in the field of renewable energy by the new generation FTAs of the EU and their effects on international renewable energy law.

To reach its renewable energy targets for 2020 and 2030, the EU needs cooperation both among Member States and with third states. A major reason for this necessity is the fact that every Member State faces different circumstances in terms of capacity, experience and internal administrative procedures while trying to reach the targets (European Union, 2009). It is also possible that the potential of renewable energy sources in every Member State 
may not be enough to achieve the objectives (European Union, 2009). From this point of view, it is important for the EU to set its renewable energy objectives for 2020 and 2030 not for each Member State, but instead, as targets to be achieved at Union level. In this way, the EU makes efforts to achieve its renewable energy targets through the cooperation among its Member States and by concluding agreements with third states.

In addition, the importance of the private sector in the field of trade and investments in renewable energy is emphasized (European Union, 2009). It is impossible for international trade in renewable energy, to which the support of the private sector is important, not to be affected by the developments. Therefore, it is necessary to review, in terms of the acquis communautaire, how the FTAs of the EU regulate the trade and investments in renewable energy which is a dynamic and major field.

This article, which reflects the entirely objective viewpoint of a legal expert, is based solely on the texts of FTAs and the Opinion 2/15 of the CJEU. Thus, available written legal documents have been reviewed in accordance with the aim of the article. As the methodology of the research, the provisions on renewable energy in the examined written legal documents have been discussed in accordance with the aim of the article. The relation between said provisions and the provisions of the Directive 2009/28/EC and the Directive 2018/2001 and the articles of the Treaty on European Union ("TEU") and the Treaty on the Functioning of the European Union ("TFEU") regarding renewable energy has been discussed.

The research for this article also covers the provisions on renewable energy in the EU-Vietnam Free Trade Agreement, which became effective on 1 August 2020. Hence, the article is based on a research that considers the current developments regarding renewable energy, which is a dynamic subject in the acquis communautaire. Therefore, the subject of the article and the findings obtained are important in that they reveal how the acquis communautaire shapes the international renewable energy law.

This article is structured in three main sections: The first section tries to identify the general characteristics of EU's Common Commercial Policy ("CCP") and the status of renewable energy in CCP. The second section discusses how EU's foreign policy regarding renewable energy is formed within the framework of the acquis communautaire. The last section chronologically reviews the provisions on renewable energy in the FTAs which have been concluded by the EU with third states and entered into force, and seeks an answer to the research question.

The main finding of the article is that the EU, which acts more strongly due to its exclusive competence in the field of trade and investment in renewable 
energy, shapes the international renewable energy law through the values and regulations in acquis communautaire. Another finding is that standardization, by the EU and in accordance with acquis communautaire, of the renewable energy sections in the FTAs concluded with third states adds to the importance of the acquis communautaire.

\section{General Characteristics of the EU's Competence Related to CCP}

The EU manages trade relations with non-EU countries through its CCP, according to Article 206 of the TFEU (Treaty on the Functioning of the European Union, 1957, Art. 206). The specific commercial policy objectives mentioned in Article 206 of the TFEU have applied since 1958 without any modifications. The only exception newly added by the Treaty of Lisbon is the obligation for "the progressive abolition of restrictions on foreign direct investment and the lowering of customs and other barriers" (Vedder, 2013: 120). As an important provision, the first paragraph of the Article 207 of the TFEU stipulates:

The common commercial policy shall be based on uniform principles, particularly with regard to changes in tariff rates, the conclusion of tariff and trade agreements relating to trade in goods and services, and the commercial aspects of intellectual property, foreign direct investment, the achievement of uniformity in measures of liberalisation, export policy and measures to protect trade such as those to be taken in the event of dumping or subsidies. The common commercial policy shall be conducted in the context of the principles and objectives of the Union's external action (TFEU, 1957, Art. 207, Para. 1).

Implementing the CCP, "the EU tries to balance the interests of the Member States and of the different stakeholders such as consumers, producers, importers and exporters, with a view to ensuring fair competitive conditions for European companies, allowing the import of raw materials and other productive inputs into Europe, making available more goods and services to European consumers" (Directorate-General for External Policies Policy Department, 2015: 18-19). Although "the division of CCP-related competences between Member States and the EU makes negotiation and conclusion of new trade and investment agreements difficult for third parties" (Nakanishi, 2017: 459), the CCP policy is regulated as "an exclusive competence of the EU - so only the EU, and not individual Member States, can legislate on trade matters and negotiate international trade agreements, be they multilateral, regional or bilateral" (Delegation of the European Union to Vietnam, 2019: 25). Thus, renewable energy chapters, which are included within the FTAs under the CCP policy of the EU, are also subject to the EU's exclusive competence, although Member States also have a competence "to determine its choice between 
different energy sources" (Treaty on the Functioning of the European Union, 1957, Art. 194, Para. 2).

The reason for the transfer of competences related to setting the CCP, including foreign direct investments in renewable energy according to the EU's policy on energy which is regulated in the first paragraph of the Article 194 of the TFEU, is the aim to strengthen the role of the EU in international trade, since the EU has stronger negotiating powers as a union in comparison each of its Member States. The EU then, "with its new competences, will be able to negotiate investment treaties with market access provisions as well as preestablishment treatment more forcefully" (Bungenberg 2010: 142). The CCP, which will strengthen the EU in international trade, will also be followed on the basis of the principles and objectives of the EU's external action pursuant to first paragraph of Article 207 of the TFEU, and it may be predicted that acquis communautaire will affect international law to a larger extent. The reason is that one of the EU's main objectives is to "uphold and promote its values in its relations with the wider world" (Treaty on European Union, 1992, Art. 3, Para. $5)$.

The EU's external policy increasingly focuses on the export of the EU's own rules and procedures (Elsuwege, 2014: 218). The CCP and the foreign trade are also part of this "value-oriented integral external policy of the EU" (Vedder, 2013: 144). Sustainable development, which is closely related to renewable energy, is one of the values upheld and supported by the EU in its foreign policy and the FTAs it concludes, due to the binding objectives related to the CCP listed in second paragraph of Article 21 of the TEU (Bungenberg, 2010: 149). A consequence of the EU's exclusive power to set a CCP and conclude FTAs is that the agreements concluded by the EU are required to be implemented in its internal law (Müller-Ibold, 2013: 153). The rules set by the EU and the third party, which conclude an FTA within the framework of the $\mathrm{CCP}$, gain a place in the internal law of each Member State. Likewise, this also means that acquis communautaire, created by the Member States, affects the law of the other party to the FTA that is concluded. Consequently, a uniform understanding of trade arises (Müller-Ibold, 2013: 145).

\section{Enabling an External EU Policy on Renewable Energy}

The EU had been searching for legal solutions to eliminate the need for energy importation and to fulfill its commitments under international agreements for climate change mitigation. Therefore, beginning with the Council's Recommendation dated 8 June 1988, increasing the exploitation of renewable energy sources in overall consumption became one of the high priority objectives of the EU (Council of the European Communities, 1988). Furthermore, in parallel with the development of renewable technologies, trade 
of goods and products in renewable energy has also started gaining importance for the EU. Through the Global Trade Strategy adopted in 2006, the EU highlighted the importance of tackling non-tariff barriers, eliminating restrictions on access to sources such as energy and raw materials (Guclu, 2018: 20).

The way in which the competence in the energy field will be shared between the EU and its Member States is determined by the relevant provisions that govern the energy field in the TFEU, one of which is Article 194 of the TFEU. The TFEU unfortunately doesn't contain any formula with a precise configuration on power sharing (Delvaux 2013: 313). Agreements on trade in renewables or energy-efficiency technologies again fall under Article 207 of the TFEU. By contrast, the third subparagraph of the first paragraph of Article 194 is the applicable legal base where the EU wishes to cooperate internationally on promoting renewables and energy efficiency (Roeben, 2018: 171). "Union policy on energy shall aim, in a spirit of solidarity between Member States, to [...] (c) promote energy efficiency and energy saving and the development of new and renewable forms of energy" (Treaty on the Functioning of the European Union, 1957, Art. 194, Para. 1/c).

In addition to understanding the legal basis of the acquis communautaire regarding the renewable energy trade, the provision in the second paragraph of Article 21 of TEU also has an importance. The Article states:

The Union shall define and pursue common policies and actions, and shall work for a high degree of cooperation in all fields of international relations, in order to ... encourage the integration of all countries into the world economy, including through the progressive abolition of restrictions on world trade" (TEU: 1992, Art. 21, Para. 2/e).

Considering together with the Article 194 of the TFEU, it shows that the EU has a legal obligation to encourage all countries to integrate the trade in renewable energy goods and products as well, and it realizes this by eliminating the trade barriers on the investments and goods in the field of renewable energy. Actually, this situation results from the fact that the content of the second paragraph of Article 21 of the TEU is comprehensive and it is interpreted in broad terms. The integration into the world economy referred to in the second paragraph of Article 21 of the TEU does not only refer to the removal of trade barriers, but also to the enhancement of trading power of all countries by sustainable development and is thus mutually related with the trade in renewable energy. In this regard, as discussed in the next section, it is a result of the reflection of the EU legislation that in FTAs concluded with Singapore and Vietnam, the Parties agree on the removal of trade barriers in renewable energy products and goods, and on the promotion of these principles also regionally and globally. 
In parallel with the approaches explained above, the same view is shared by the Court of Justice of the European Union ("CJEU") as well. As reviewed in detail in the next section, the CJEU has given its opinion on whether the FTA concluded by the EU with Singapore falls within the competence of the EU or the Member States or both. Accordingly, the CJEU confirmed in its Opinion $2 / 15$ that trade in goods and other areas strongly linked to trade in goods and services such as trade and investment in renewable energy generation, trade facilitation and customs, technical barriers to trade, competition and government procurement fall under the CCP (Court of Justice of the European Union, 2017).

Besides its internal law, another legal aspect that enables the EU to reach an agreement with third states in the field of renewable energy while concluding FTAs is the understanding of this field which has formed in the international law. As an example to prove that assertion, in 2015, the United Nations General Assembly adopted a resolution called the "2030 Agenda for Sustainable Development". The Declaration spells out the goal of "universal access to affordable, reliable and sustainable energy with a substantially increased share of renewable energy in the global energy mix." (United Nations General Assembly, 2015). The terms of this goal evidently overlap with those employed by the European Energy Union Strategy (Roeben, 2018: 39).

\section{The Characteristics of Renewable Energy Chapters in FTAs of the EU}

In the previous sections, the basic principles underlying EU's CCP and the status of renewable energy in said policy were discussed. In addition, efforts were made to explain the legal basis of EU's foreign policy in the field of renewable energy. These subjects are important because it is necessary to comprehend the CCP of the EU, which covers the field of renewable energy as well, and the legal basis in the acquis communautaire in order to understand how the acquis communautaire shapes the international renewable energy law.

Before proceeding to the review of the provisions on renewable energy in EU's FTAs with third states, it is necessary to mention two important Directives. The provisions of these two Directives make it possible for the EU to conclude FTAs with third states to achieve its objectives for 2020 and 2030.

The EU decided its first Directive which included binding targets to increase the share of the energy consumption from renewable sources in overall energy consumption by accepting the "Directive 2009/28/EC of the European Parliament and of the Council of 23 April 2009 on the promotion of the use of energy from renewable sources and amending and subsequently repealing Directives 2001/77/EC and 2003/30/EC" ("former RES Directive"). In order to reach the binding targets, the Articles 7 and 9 of the former RES Directive allow the Member States to establish joint projects between each other and also 
between one or more Member State(s) and third countries. Furthermore, the Articles 9 and 11 of the "Directive 2018/2001 on the promotion of the use of energy from renewable sources" ("new RES Directive". Hereinafter, the Directives 2009/28/EC and 2018/2001 referred together to as "RES Directives") continues to allow the Member States to establish joint projects between each other and also between one or more Member States and third countries.

Not only has the legal basis of EU's CCP in the field of renewable energy been determined, but also the basis of the relevant Directives in the provisions regarding renewable energy in FTAs has been explained. On this basis, with a view to understanding how acquis communautaire shapes the international renewable energy law, it is now possible to review the provisions on renewable energy in the FTAs concluded by the EU with third states, which have entered into force.

The first FTA concluded by the EU in accordance with the new provisions of the TFEU was the one with South Korea ("Free Trade Agreement between the European Union and its Member States, of the one part, and the Republic of Korea, of the other part". Hereinafter referred to as "EUSKFTA"), which includes provisions also regarding sustainable development (European Union, 2011).

Along with the former RES Directive and the Treaty of Lisbon, the EUSKFTA provides the first examples of the provisions in renewable energy, which were determined to be a part of the values to be handled within the framework of the CCP, upheld and promoted by the EU. The second paragraph of Article 13.6, titled "Trade Favouring Sustainable Development", of the agreement reads as follows:

The Parties shall strive to facilitate and promote trade and foreign direct investment in environmental goods and services, including environmental technologies, sustainable renewable energy, energy efficient products and services and eco-labelled goods, including through addressing related non-tariff barriers. The Parties shall strive to facilitate and promote trade in goods that contribute to sustainable development, including goods that are the subject of schemes such as fair and ethical trade and those involving corporate social responsibility and accountability (European Union, 2011).

The relevant provision discusses renewable energy together with the fields of sustainable development, fair and ethical trade and social responsibility. Said provision clearly shows us that, even though renewable energy is not cited in the fifth paragraph of the third Article of the TEU (Treaty on European Union, 1992, Art. 3, Para. 5) among the values to be upheld by the EU against the 
wider world, it has a place in FTAs of the EU along with sustainable development, to which it is directly related.

Another principle upheld by the EU alongside renewable energy is its international obligations. From this perspective, the international obligations made by the EU with respect to climate change mitigation are the basis of the struggle it intends to win by boosting the share of renewable energy globally. Within this context, the second paragraph of Article 24.9 of the "Comprehensive Economic and Trade Agreement (CETA) between Canada, of the one part, and the European Union and its Member States, of the other part", concluded with Canada (hereinafter referred to as "CETA with Canada"), is an indicator that the Parties are determined to fulfill their international obligations in climate change mitigation, where renewable energy is pointed as a solution. The provision reads as:

[The parties] shall, consistent with their international obligations, pay special attention to facilitating the removal of obstacles to trade or investment in goods and services of particular relevance for climate change mitigation and in particular trade or investment in renewable energy goods and related services. (European Union, 2017).

Indeed, the EU's environmental awareness and its determination to fulfill its obligations regarding international law are also manifested in Article 24.12 of the same agreement. Said provision reads as:

The Parties recognize that enhanced cooperation is an important element to $[\ldots]$ commit to cooperate on trade-related environmental issues of common interest, in [...] trade and investment in environmental goods and services, including environmental and green technologies and practices; renewable energy; energy efficiency; and water use, conservation and treatment (European Union, 2017).

Another example of the FTAs where the EU handles renewable energy provisions together with sustainable development and climate change is the "Agreement Between the European Union and Japan For an Economic Partnership" (hereinafter referred to as "EUJFEP"). As a matter of fact, subparagraph (b) of Article 16.5 of said agreement, titled Trade and Investment Favouring Sustainable Development, reads as follows:

Accordingly, the Parties:

$[\ldots]$

(b) shall strive to facilitate and promote trade and investment in environmental goods and services, in a manner consistent with this Agreement;

(c) shall strive to facilitate trade and investment in goods and services of particular relevance to climate change mitigation, such as those related to 
sustainable renewable energy and energy efficient goods and services, in a manner consistent with this Agreement (European Union, 2018a).

Each FTA concluded within the framework of the CCP, for which the EU has had competence since the effective date of the Treaty of Lisbon, stands on the background created by the previous FTA. While elimination of trade barriers, emphasized in the second subparagraph of Article 1.1 of EUSKFTA (European Union, 2011), forms the basis of the subsequent FTAs, each subsequent FTA regulates a new field in renewable energy.

In this respect, the "Free Trade Agreement Between the European Union and the Republic of Singapore" (hereinafter referred to as "EUSFTA"), which has recently become effective, may be cited as an example (European Union, 2019). The EUSFTA has broadened the role and scope of renewable energy in the FTAs of the EU and discussed the trade in renewable energy as a separate chapter (European Union, 2019). Indeed, in the FTAs until the EUSFTA, the EU handles renewable energy along with the principles of sustainable development or climate change mitigation or promotion of trade in this field; however, in its recent FTAs concluded after the EUSFTA, renewable energy constitutes an agreement chapter by itself.

Another state with which the EU has recently concluded an FTA is Vietnam ("Free Trade Agreement Between the EU and the Socialist Republic of Viet Nam". Hereinafter referred to as "EUVFTA"). The agreement entered into force as of 1 August 2020 (European Commission, 2020). Relevant provisions in the seventh Chapter of the EUSFTA are maintained in the seventh Chapter of the EUVFTA with almost identical sentences and under the same title, "NonTariff Barriers to Trade and Investment in Renewable Energy Generation " (European Union, 2020).

In relation to renewable energy constituting an independent chapter in the EUVFTA, the EU stated that Vietnam can benefit from the successful experiences of the EU in the field of renewable energy thanks to this agreement. It pointed out that the rules, set clearly and transparently for this purpose, will create trade opportunities in this field and raise awareness in investors. It was also emphasized that the EUVFTA brought along added values as well. With an emphasis that this FTA was not an agreement signed by the EU and Vietnam merely to take advantage of commercial opportunities, but it was going to contribute to climate change mitigation as well, it was stated that a wider use of renewable energy played a major role in climate change mitigation (Delegation of the European Union to Vietnam, 2019: 61). When we review the section on "Non-Tariff Barriers to Trade and Investment in Renewable Energy Generation", which constitutes the seventh Chapter of the FTAs with Singapore and Vietnam, we can determine the following principles in the renewable energy acquis that the EU has been trying to form on a global scale: 


\section{To remove or reduce tariffs as well as non-tariff barriers}

The objective, which is specified in Article 7.1 of the same Chapters, is to reduce greenhouse gas emissions in line with global efforts. As mentioned in the section above, among the most important factors underlying the intention of the EU in its FTAs to fulfill its commitments related to climate change, appreciation of this intention by the third party, and formation of provisions that can be agreed upon in relation to clean and renewable energy are the importance attached globally to climate change mitigation and the resulting universal understanding in this field. Within this context, in the FTAs, the "Parties share the objective of promoting, developing and increasing the generation of energy from renewable and sustainable non-fossil sources, particularly through facilitating trade and investment" (European Union, 2019; European Union, 2020). To ensure that energy generation from renewable and sustainable fuels can be increased through trade and investment, "the Parties shall cooperate towards removing or reducing tariffs as well as non-tariff barriers" (European Union, 2019; European Union, 2020).

2. To cooperate on fostering regulatory convergence with or towards regional and international standards

This provision is the most evident indicator of the intention of the EU to create a renewable energy network based on a single legal acquis on a global scale. Indeed, the EU makes it clear with the standardized renewable energy provisions that it aims at forming regional and international standards with the FTAs, and will pursue the same goal with its subsequent FTAs (European Union, 2019; European Union, 2020).

3. To decide the legal definitions for the implementation of the renewable energy provisions

Article 7.2 of the FTAs with Singapore and Vietnam, as it exists in the EU law, also contains a section with definition of terms to ensure transparency and comprehensibility for both the Parties and the investors. In the definitions listed in Article 7.2 of the FTAs with Singapore and Vietnam, the term "measure" draws attention. This is explained as: "any measure within the scope of this Chapter that is taken by a Party, whether in the form of a law, regulation, rule, procedure, decision, administrative action, or any other form" (European Union, 2019; European Union, 2020).

Although Article 13 of the former RES Directive defines the powers of the EU Member States to introduce the necessary regulations defined as administrative procedures, regulations and codes, as referred to in the next section, an effort was made to balance these powers through principles such as the requirement to adopt non-discriminatory, objective and transparent 
regulations, where the stages of granting permit and licensing are proportionate and the timeline is clear. Partnerships between local companies and companies of the other Party are also encouraged and local development is aimed with the "measures requiring the formation of partnerships with local companies" and "offset" in the definitions (European Union, 2019; European Union, 2020).

\section{To determine the scope of renewable energy sources}

As in the former RES Directive, the EU clearly defines the sources of renewable energy in the FTA chapters related to renewable energy. Article 7.3 of the EUSFTA states that provisions related to renewable energy:

apply to measures which may affect trade and investment between the Parties related to the generation of energy from renewable and sustainable non-fossil sources, namely wind, solar, aerothermal, geothermal, hydrothermal and ocean energy, hydropower, biomass, landfill gas, sewage treatment plant gas and biogases, but not to the products from which energy is generated (European Union, 2019; European Union, 2020).

In this way, it was stated numerus clausus what sources will be covered by the renewable energy provisions that are intended to be standardized on a regional and global scale. If close attention is paid, it may be seen that the renewable energy sources covered by the renewable energy chapters in the FTAs and those for which the EU member states are bound to achieve a target pursuant to the RES Directives are the same. In Article 2(a) of the former RES Directive, which contains definitions, the types of energy obtained from renewable sources are listed as follows:

'energy from renewable sources' means energy from renewable nonfossil sources, namely wind, solar, aerothermal, geothermal, hydrothermal and ocean energy, hydropower, biomass, landfill gas, sewage treatment plant gas and biogases.

It is interesting that this definition in the former RES Directive is included in exactly the same form in the EUSFTA. A comparative research regarding this subject will reveal that some other international documents contain different definitions of renewable energy. For example, the OECD defines the content of renewable energy as follows: "They include energy generated from solar, wind, biomass, geothermal, hydropower and ocean resources, solid biomass, biogas and liquid biofuels." (Lagefoged, 2010: 29).

The United Nations, on the other hand, defines the content of renewable energy in a different way: "New and Renewable Energy Sources: energy sources including solar energy, geothermal energy, wind power, hydropower, ocean energy (thermal gradient, wave power and tidal power), biomass, draught 
animal power, fuelwood, peat, oil shale and tar sands." (United Nations Statistics Division, 2020).

As it may be noticed, international documents contain a wide variety of definitions as to the content of renewable energy. Nevertheless, while defining the content of renewable energy sources in the EUSFTA, the provision in Article 2(a) of the former RES Directive of the EU was maintained without any changes, instead of referring to the provisions in the other international legal texts that define the content of renewable energy sources. This preference is a clear proof that how the EU started shaping the international law in renewable energy. This is important since the EU, due to its position as the largest energy importer and consumer in the world (Council of the European Union, 2019) and also a renewable energy technologies provider, has geopolitical and strategic interests in developing its foreign renewable energy relations with its trade partners worldwide (Boute, 2014:239). While developing these relations, the EU promotes its legislation as a model during negotiations since it has said interests. From the point of view of the Commission, having market transparency and regulations at the highest level in the world (European Commission, 2011:9) and promoting this legislation in its international collaborations, the EU not only promotes legal regulations based on good practices in renewable energy trade and investments to third countries, but also manages to create a uniform and standard legislation by promoting its own legislation to its trade partners worldwide and shaping the international trade in renewable energy in accordance with its own legislation (Boute, 2014:257).

\section{To adopt the Principles}

Article 7.4 of the FTAs with Singapore and Vietnam specifies the principles to be followed by the third parties concluding an FTA with the EU. In accordance with the relevant article;

Each Party shall:

(a) refrain from adopting measures providing for local content requirements or any other offset affecting the other Party's products, service suppliers, entrepreneurs or establishments;

(b) refrain from adopting measures requiring the formation of partnerships with local companies, unless such partnerships are deemed necessary for technical reasons and the Party can demonstrate such technical reasons upon request by the other Party;

(c) ensure that any rules concerning the authorisation, certification and licensing procedures that are applied, in particular to equipment, plants and associated transmission network infrastructures, are objective, transparent, and nonarbitrary, and do not discriminate against applicants from the other Party; 
(d) ensure that administrative charges imposed on or in connection with the:

(i) importation and use of goods originating in the other Party, or affecting the provision of goods by the other Party's suppliers, are subject to Article 2.10 (Fees and Formalities Connected with Importation and Exportation); and

(ii) provision of services by the other Party's suppliers are subject to Article 8.18 (Scope and Definitions), Article 8.19 (Conditions for Licensing and Qualification) and Article 8.20 (Licensing and Qualification Procedures); and

(e) ensure that the terms, conditions and procedures for the connection and access to electricity transmission grids are transparent and do not discriminate against suppliers of the other Party. (European Union, 2019; European Union, 2020).

Among the principles specified in third paragraph of Article 4, the ban on discrimination stands out. It is particularly emphasized that, while administrative conditions and procedures are determined, applicants from the other party may not be discriminated against in favor of local applicants and the process must be transparent. It is also stated that partnership with local companies is a measure that may be taken only if it is necessary for technical reasons. Naturally, said principles specified in Article 7.4 also bind the EU as the other party. The provision referred to above brings to mind the new RES Directive. Under said Directive, Member States aim to remove the administrative barriers to the permit and license procedures for renewable energy investments and ensure that such procedures are transparent, fast and objective (par. 51). In this way, it is aimed to ensure that none of the Member States performs an administrative procedure that constitutes discrimination against an investor from another Member State, and a Common Market based on a single acquis is formed in renewable energy. The same principles are also adopted in the FTAs concluded by the EU with third countries due to the intention to encourage investors in renewable energy and benefit from the experience of the private sector. This is because governance is often discussed as new governance, with an emphasis on private-sector involvement, in the literature on the EU (Roeben: 2018, 22).

\section{To be in Conformity with International Standards}

In the first paragraph of Article 7.5 of the EUSFTA, the efforts of the EU to ensure economic integration of all countries worldwide in the field of renewable energy may be obviously seen. Said article states that:

Where international or regional standards exist with respect to products for the generation of energy from renewable and sustainable non-fossil sources, the Parties shall use those standards, or the relevant parts of 
those standards, as a basis for their technical regulations except when such international standards or relevant parts would be an ineffective or inappropriate means for the fulfilment of the legitimate objectives pursued... (European Union, 2019).

Furthermore, it is emphasized that "[f]or the purpose of applying this paragraph, the International Organization for Standardization (hereinafter referred to as 'ISO') and the International Electrotechnical Commission (hereinafter referred to as 'IEC'), in particular, shall be considered relevant international standard-setting bodies." (European Union, 2019). The provision regarding international and regional standards provided in the first paragraph of Article 7.5 of the EUSFTA was maintained with almost no changes in the second paragraph of Article 7.5 of the EUVFTA (European Union, 2020).

\section{To determine the exceptions}

The second paragraph of Article 7.6 emphasizes the responsibilities of the Parties to not to allow the implementation of the measures in a discriminatory way and to adopt the necessary measures to ensure that the energy networks are operated safely:

For greater certainty, subject to the requirement that such measures are not applied in a manner which would constitute a means of arbitrary or unjustifiable discrimination between the Parties' products, service suppliers or investors where the same conditions prevail, or a disguised restriction on trade and investment between the Parties, nothing in this Chapter shall be construed as preventing a Party from the adoption or enforcement of measures necessary for the safe operation of the energy networks concerned, or the safety of energy supply (European Union, 2019; European Union, 2020).

\section{To cooperate with the Parties of the FTAs}

The constantly-evolving nature of the field of renewable energy, in particular the renewable technologies, encourages the Parties to remain in cooperation during the effective term of the FTA. Therefore, the EU considered this fact in the FTAs with Singapore and Vietnam and referred to the importance of the coordination between the Parties in Article 7.7 of these agreements. In this way, the Trade Committee to be formed pursuant to the FTAs with Singapore and Vietnam is instructed "to cooperate and exchange information on any issues relevant to the implementation of the chapter related to renewable energy" (European Union, 2019; European Union, 2020). It is also emphasized that the Parties may adopt appropriate measures by the decision of the Trade Committee. 
Said Article of the EUSFTA states that

this cooperation may include [...] the design and non-discriminatory implementation of measures promoting the uptake of energy from renewable sources, carbon capture and storage, smart grids, energy efficiency and technical regulations, standards and conformity assessment procedures, such as those relating to grid code requirements, and promoting [...] the convergence of their domestic or regional technical regulations, regulatory concepts, standards, requirements and conformity assessment procedures with international standards (European Union, 2019).

A provision regarding the cooperation between the Parties, which has almost the same content, is also provided in the second paragraph of Article 7.7 of the EUVFTA (European Union, 2020). It was stated hereinbefore that the provisions regarding renewable energy were further expanded in the FTAs concluded by the EU within the framework of its CCP after the Treaty of Lisbon, and each FTA was built on the previous one. Indeed, CETA with Canada and the EUSKFTA did not contain renewable energy as the topic of a separate chapter; instead, they referred to the importance of renewable energy only indirectly in the chapter concerning trade and investments that foster sustainable development. Although EUSFTA and EUVSTA contained a separate chapter related to renewable energy, it may also be noticed that the topics emphasized in relation to renewable energy in the CETA with Canada and the EUSKFTA are also not ignored. Pursuant to the second subparagraph of Article 12.11 of the EUSFTA, titled Trade and Investment Promoting Sustainable Development, the document states: "The Parties shall pay special attention to facilitating the removal of obstacles to trade or investment concerning climate-friendly goods and services, such as sustainable renewable energy goods and related services and energy efficient products and services" (European Union, 2019). Renewable energy is maintained as one of the major elements of sustainable development. Other provisions that contain basic principles regarding promotion of renewable energy investments and trade are the third and fourth subparagraphs of the same article. Indeed, the third subparagraph states that development of a sustainable and safe low-carbon economy is possible through investment in renewable energies and energyefficient solutions. The fourth subparagraph emphasizes the Parties agreed that, when promoting trade and investment, they should make special efforts to promote corporate social responsibility practices:

3. ...both Parties will actively promote the development of a sustainable and safe low-carbon economy, such as through investment in renewable energies and energy efficient solutions. 
4. When promoting trade and investment, the Parties should make special efforts to promote corporate social responsibility practices which are adopted on a voluntary basis... (European Union, 2019).

In the FTAs the EU has concluded since the Treaty of Lisbon, it handles renewable energy in a more comprehensive way and uses definitive, regulatory and interpretative provisions in these FTAs. Even though renewable energy is not directly mentioned in second paragraph of Article 21 of the TEU, and in Articles 206 and 207 of the TFEU, the EU attaches more importance to renewable energy in its FTAs by regulating removal of tariffs and non-tariff barriers to trade, upholding the values of the EU in international relations, encouraging integration of countries worldwide into international trade, and in addition, applying its principles of climate change mitigation and social responsibility. The EU agrees on its aforementioned principles with other Party in the FTAs, and in this way, shapes international law thanks to its technological and legal experience and background in renewable energy. In case the EU manages to ensure an international standardization in renewable energy, this will make it easier to export and import goods and products used to generate renewable energy. This situation also helps with the removal of a wide range of obstacles to trade in these goods and products that are implemented in addition to customs tariffs (European Commission, 2018: 7).

As explained in the above-mentioned articles of the FTAs, the impacts of the CCP of the EU have a significant guiding role in renewable energy. The chapters of these new generation FTAs related to renewable energy may be categorized in three sections as explained below, depending to their importance:

(a) the reduction of technical barriers to trade in energy materials (the elimination of technical barriers to trade and investment in equipment aimed at generating renewable energy),

(b) the elimination of export duties on energy resources and

(c) the opening of new business opportunities in the provision of services or in government procurement (Directorate-General for External Policies Policy Department, 2015: 32).

These characteristics of the new generation FTAs demonstrate how the EU acts in relation to promoting renewable energy. And the EU, having exclusive competence in establishing the $\mathrm{CCP}$, shapes the provisions of international law in renewable energy by giving the renewable sources full play in the FTAs and trying to globalize its values by both performing its international obligations and removing the barriers in export and import of renewable energy goods and technologies. As a result of this policy, introducing chapters regarding renewable energy in FTAs helps to enable the creation of a globally uniform legal acquis in renewable energy and to make trade in renewable energy more 
feasible and competitive (Leal-Arcas, Caruso and Leupuscek, 2015: 483). The observations made and results obtained in this research indicate that globalization of the trade and investments in renewable energy is very important to the CCP of the EU. The second paragraph of the Preamble to the new RES Directive discusses the significance of renewable energy to the EU as follows:

The increased use of energy from renewable sources or 'renewable energy' constitutes an important part of the package of measures needed to reduce greenhouse gas emissions and comply with the Union's commitment under the 2015 Paris Agreement on Climate Change following the 21st Conference of the Parties to the United Nations Framework Convention on Climate Change (the 'Paris Agreement'), and with the Union 2030 energy and climate framework, including the Union's binding target to cut emissions by at least $40 \%$ below 1990 levels by 2030. The Union's binding renewable energy target for 2030 and Member States' contributions to that target, including their baseline shares in relation to their national overall targets for 2020, are among the elements which have an overarching importance for the Union's energy and environmental policy (European Union, 2018b).

In addition, Article 3(1) of the Directive states: "Member States shall collectively ensure that the share of energy from renewable sources in the Union's gross final consumption of energy in 2030 is at least $32 \%$ " (European Union, 2018b) Thus, the EU also needs to encourage and regulate the trade and investments in renewable energy, to both fulfil its commitments under the Paris Agreement and achieve the binding targets in the Directive 2018/2001. Therefore, as stated in Article 11 of the Directive 2018/2001, joint projects between third states and the EU Member States are allowed like in Article 9 of the former RES Directive. The remarks of the EU Commission also reveal that achieving the renewable energy targets is possible only by ensuring the participation of the private sector in both the EU Member States and third states: "Pushing for a global deal for climate change and encouraging private investment in new infrastructure and technologies. Supporting breakthroughs in low-carbon technologies by coordinating research and helping to finance projects in partnership with the private sector" (European Commission, 2019). Due to the binding targets in renewable energy as well as the developments in renewable technologies and the experience of the private sector in this field, it is obvious that the EU will attach much more importance to the regulations in the renewable energy chapters in new generation FTAs in order to increase the trade and investments in renewable energy.

\section{Conclusion}

This article is an effort to prove that, in the field of trade and investments in renewable energy, the EU shapes the international law through the FTAs it has 
concluded, which have entered into force. It also tries to back the argument that the EU leads the process of forming a uniform legislation, which is becoming a standard in the international renewable energy law, through these FTAs. Within this framework, it is important to determine first of all the status of renewable energy in the common commercial policy of the EU so that the major role of the provisions on renewable energy in the FTAs can be understood.

Pursuant to Article 207(1) of the TFEU, concluding of FTAs falls under the common commercial policy, over which the EU has exclusive competence. Therefore, provisions regarding renewable energy, which constitute a part of the FTAs concluded by the EU, are decided on at the Union level as well. Opinion 2/15 of the CJEU has conclusively determined that the trade in goods and other areas strongly linked to trade in goods and services such as trade and investment in renewable energy generation, trade facilitation and customs, technical barriers to trade, competition and government procurement fall under the CCP.

Under fifth subparagraph of the second paragraph of Article 21 of the TEU, the EU encourages gradual removal of the restrictions on international trade in renewable energy, and consequently, the integration of all countries into the world economy. As a natural consequence of this provision, within the framework of the acquis communautaire, the EU has committed itself to ensuring integration of all countries in the field of trade and investment in renewable energy and must set its policies accordingly.

Under the Directives 2009/28/EC and 2018/2001, it has been made possible for the EU to cooperate with third states to increase the share of renewable energy in total energy consumption. Therefore, it is important to review the provisions regarding renewable energy in the FTAs concluded by the EU with third states. Indeed, the FTAs concluded by the EU are the best reflections of both the provision in fifth subparagraph of the second paragraph of Article 21of the TEU and the provisions in the Directives. Beginning from the FTA concluded with South Korea, each FTA was built and developed on the values of the previous one. However, in the FTA concluded with Singapore, which precedes the one with Vietnam, renewable energy constitutes a chapter by itself, and this chapter was adopted in the Vietnam FTA with almost the same content. On the basis of this information, it has been determined that the provisions regarding renewable energy have been standardized in EU's FTAs. As a result, it may be argued that the same standard provisions related to renewable energy will be maintained in the future FTAs of the EU.

In conclusion, it is observed that the EU has matured its renewable energy policies, which it formed over a long period of struggle. Since the EU is the largest energy importer and consumer in the world and also a renewable energy 
technologies provider, it has geopolitical and strategic interests in developing its foreign renewable energy relations with its trade partners worldwide pursuant to Article 207 of the TFEU and on the basis of Opinion 2/15 of the CJEU. While developing these relations, the EU not only promotes its acquis communautaire based on good practices in renewable energy trade and investments to its trade partners worldwide, but also manages to create a uniform and standard legislation by shaping the international trade and investment in renewable energy in accordance with its acquis communautaire. These external policies of the EU in trade and investment in renewable energy results in the formation of a uniform text in international renewable energy law. 


\section{References:}

Boute, A. (2014) "The EU's Shaping of International Law on Energy Efficiency", in D. Kochenov and F. Amtenbrick (ed.), The European Union's Shaping of the International Legal Order, (Cambridge: Cambridge University), pp: 238-260.

Bungenberg, M. (2010) "Going Global? The EU Common Commercial Policy After Lisbon", in C. Herrmann and J. Philipp Terhechte (ed.), European Yearbook of International Economic Law, (Heidelberg: Springer Verlag), (1): 123-152.

Council of the European Communities (1988) "Council Recommendation of 9 June 1988 on developing the exploitation of renewable energy sources in the Community", Official Journal of the European Union, L 160, p. 0046 0048, 28 June1988.

Council of the European Union (2019) "Infographic - Clean energy for Europeans: Key for driving forward the Energy Union", 11 July, $<$ https://www.consilium.europa.eu/en/infographics/energy-union/>, November 2019).

Court of Justice of the European Union (2017) "Opinion 2/15 of the Court", 16 May, <http://curia.europa.eu/juris/document/document.jsf?docid=190727 \&text $=\&$ doclang $=\mathrm{EN} \&$ pageIndex $=0 \& \mathrm{cid}=10449628>,(20$ April 2020).

Delvaux, B. (2013) EU Law and the Development of a Sustainable, Competitive and Secure Energy Policy: Opportunities and Shortcomings, (the UK: Intersentia Publishing).

Delegation of the European Union to Vietnam (2019) "Guide to the EUVietnam Trade And Investment Agreements", 1 March, <https://trade.ec. europa.eu/doclib/docs/2016/june/tradoc_154622.pdf>, (20 November 2019).

Directorate-General for External Policies Policy Department (2015), "Trade and Investments in Energy in the Context of the EU Common Commercial Policy", 1 October, <https://www.europarl.europa.eu/RegData/etudes /STUD/2015/535001/EXPO_STU(2015)535001_EN.pdf>, (14 April 2020).

European Commission (2011) "Communication from The Commission to the European Parliament, the Council, the European Economic and Social Committee and the Committee of the Regions On Security of Energy Supply and International Cooperation - "The EU Energy Policy: Engaging with Partners beyond Our Borders", Brussels, 7 September, <https://eurlex.europa.eu/legal-content/EN/TXT/PDF/?uri=CELEX:52011DC0539\& from=en>, (17 September 2020).

European Commission (2018) "Guide to the EU-Singapore Free Trade Agreement and Investment Protection Agreement”, Brussels, 1 April, 
$<$ https://trade.ec.europa.eu/doclib/docs/2018/april/tradoc_156711.pdf >, (13 April 2020).

European Commission (2019) "What is the Energy Union about?", 9 April, $<$ https://ec.europa.eu/eurostat/cache/infographs/energy/bloc-1.html>, December 2019).

European Commission (2020) "Press Release: EU-Vietnam Trade Agreement Enters Into Force", 31 July, <https:/www.europarl.europa.eu/legislativetrain/theme-international-trade-inta/file-eu-vietnam-free-trade-agreement>, (15 August 2020).

European Union (2006) "Regulation (EC) No 1905/2006 of the European Parliament and of the Council of 18 December 2006 establishing a financing instrument for development cooperation", Official Journal of the European Union, L 378, 27.12.2006, p. 41-71, <https://eur-lex.europa.eu/legalcontent/EN/ALL/?uri=CELEX\%3A32006R1905>, (17 April 2020).

European Union (2009) "Directive 2009/28/EC of the European Parliament and of the Council of 23 April 2009 on the promotion of the use of energy from renewable sources and amending and subsequently repealing Directives 2001/77/EC and 2003/30/EC (Text with EEA relevance)", Official Journal of the European Union, L 140, 5 June, p. 16-62, <https://eurlex.europa.eu/legal-content/EN/ALL/?uri=CELEX\%3A32009 L0028>, (12 January 2020).

European Union (2011) "Council Decision of 16 September 2010 on the signing, on behalf of the European Union, and provisional application of the Free Trade Agreement between the European Union and its Member States, of the one part, and the Republic of Korea, of the other part", Official Journal of the European Union, L 127, 14 May, p. 1-1432, <https://eurlex.europa.eu/legal-content/EN/TXT/PDF/?uri=OJ:L:2011:127:FULL\& from $=\mathrm{EN}>$, (17 September 2020).

European Union (2017) "Comprehensive Economic and Trade Agreement between Canada, of the one part, and the European Union and its Member States, of the other part", Official Journal of the European Union L 11, 14 January, p. 23-1079, <https://eur-lex.europa.eu/legal-content/EN/TXT/?uri= CELEX\%3A22017A0114\%2801\%29>, (22 November 2019).

European Union (2018a), "Agreement between the European Union and Japan for an Economic Partnership", Official Journal of the European Union, L 330, 27 December, p. 3-889, <http://publications.europa.eu/resource/ cellar/d40c8f20-09a4-11e9-81b4-01aa75ed71a1.0006.01/DOC_1>, April 2020).

European Union (2018b), "Directive 2018/2001 of the European Parliament and of the Council of 11 December 2018 on the promotion of the use of energy 
from renewable sources (Text with EEA relevance.)", Official Journal of the European Union, L 328, 21 December, p. 82-209, <https://eurlex.europa.eu/legal-content/EN/TXT/?uri=CELEX\%3A32018L2001>, April 2020).

European Union (2019), "Free Trade Agreement Between the European Union and the Republic of Singapore", Official Journal of the European Union L 294, 14 November, p. 3-755. <https://trade.ec.europa.eu/doclib/press/ index.cfm?id=961>, (22 November 2019).

European Union (2020), "Free Trade Agreement Between the European Union and the Socialist Republic of Viet Nam", Official Journal of the European Union, L 186, 12 June, p. 3-1400, <https://eur-lex.europa.eu/legalcontent/EN/TXT/PDF/?uri=CELEX:22020A0612(01)\&qid=160042794283 $6 \&$ from $=\mathrm{EN}>$, (17 April 2020).

Guclu, B. (2018), "EU Competences on Trade Policy: Opinion 2/15 and Prospects for Future EU Trade Agreements", (Istanbul: Economic Development Foundation).

Leal-Arcas R., Caruso V. and Leupuscek R. (2015), "Renewables, Preferential Trade Agreements and EU Energy Security", Laws, published online ahead of print, 7 August 2015, DOI: 10.3390/laws4030472

Müller-Ibold, T. (2013) "Common Commercial Policy After Lisbon: The European Union's Dependence on Secondary Legislation" in M. Bungenberg and C. Herrmann (ed.), European Yearbook of International Economic Law, Special Issue: Common Commercial Policy After Lisbon, (Heidelberg: Springer), (Special Issue): 145-162.

Nakanishi, Y. (2017) "Characteristics of EU Free Trade Agreements in a Legal Context: A Japanese Perspective" in M. Bungenberg and M. Krajewski (ed.), European Yearbook of International Economic Law, (Cham: Springer International Publishing), (1): 457-475.

Roeben, V. (2018) Towards a European Energy Union: European Energy Strategy in International Law, (Cambridge: Cambridge University Press).

United Nations General Assembly, (2015) "Transforming our World: The 2030 Agenda for Sustainable Development”, 25 September, $<$ https://www.unfpa.org/sites/default/files/resource-pdf/Resolution_A_RES_ 70_1_EN.pdf>, (15 April 2020).

United Nations Statistics Division, (2020), "Glossary", 25 May $<$ http://data.un.org/Glossary.aspx?q=renewable>, (22 March 2020).

Vedder, C. (2013) "Linkage to the Common Commercial Policy to the General Objectives for the Union's External Action", in M. Bungenberg and C. Herrmann (ed.), European Yearbook of International Economic Law, Special Issue: Common Commercial Policy After Lisbon, (Heidelberg: Springer Verlag), (Special Issue): 115-144. 